UDK 78.082.1 Mahler G.

Niall O'Loughlin

Univerza v Loughboroughu

Loughborough University

\title{
The Rondo in Mahler's Middle Period Symphonies: Valid Model or Useful Abstraction
}

Mahler's life was full of conflicts and anomalies. Bruno Walter was very clear in his biography that the composer was liable to fall victim to unpredictable mood shifts in his everyday dealings with people.

"The vehemence with which he objected whenever I said something unsatisfactory to him....his sudden submersion in pensive silence, the kind glance with which he would receive an understanding word on my part, an unexpected, convulsive expression of secret sorrow and, added to all this, the strange irregularity of his walk: his stamping of the feet, sudden halting, rushing ahead again - everything confirmed and strengthened the impression of demoniac obsession. ${ }^{1}$

He could be tyrannically rude but equally he could be very sympathetic, especially to someone in genuine difficulty. The chronicles of Natalie Bauer-Lechner also give us much insight into the composer's variable character.

This contradictory character inevitably found its way into his music. His music has a tendency to change its mood and direction dramatically and without warning. One can point to what Adorno ${ }^{2}$ called the Durchbruch or 'breakthrough', for example, in the finale of the First Symphony. The sudden change to F minor in the first movement of the First Symphony or the equally sudden appearance in the first movement of the Fourth of the grim fanfare that was to dominate the first movement of the Fifth both clashed with their surroundings. These musical conflicts and contradictions are particularly stark and frequent in the central purely instrumental symphonies, the Fifth, Sixth and Seventh. These works stand at a watershed in the de-

1 Bruno Walter, Gustav Mahler (London: Kegan Paul, Trench, Turner, 1937), 6.

2 Theodor W. Adorno, Mahler: A Musical Physiognomy (Chicago: Chicago UP, 1992), 11. 
velopment of the composer's music: there are occasional references to the Wunderhorn style yet there are new techniques and novel sonorities which are related to the sounds inspired by the Rückert settings. At almost every level this conflict appears: melody, counterpoint, harmony, orchestration and form. ${ }^{3}$ Although Mahler's blending of these elements is masterly, the dichotomy stands out insistently.

The last of this list of these features, the composer's use of form, deserves and has received close attention, as it is so fundamental to understanding his strategic thinking. Mahler's use of form is particularly important because it has such a pervasive influence on the understanding of the works themselves and is itself determined by so many of their other features. It is, however, an area of great controversy. Many analysts have aspired to elucidate the formal features of Mahler's music, but the level of agreement between them has generally been variable. One often finds that it is the traditional labels that are the problem, but it also involves the understanding of the workings of the music. Like his character, his form is full of contradictions. In some ways it is traditional, apparently taking Classical models as starting points, which of course is part of the fascination, but in other ways it is intuitive, flexible, modern and completely original.

One distinctive feature of Mahler's use of form, especially in these symphonies, is the way he constantly returns to his principal thematic materials. In simple or simplistic terms this is the rondo. While it seems a good starting point, it is never as straightforward as this. Rondo as a Classical form has a fairly well defined structure and equally well observed 'rules'. Mahler's use of rondo or of any kind of thematic reprise is full of philosophical, musical, logical and other difficulties and inconsistencies.

What then is a rondo? Obviously it has been and is many things. The Medieval rondeau was a form which was poetic in origin; its plan involved repeated lines and in its musical translation it used repeated melody which did not always coincide with repeated verse. For our purposes the rondo as used in the Baroque and Classical periods has more obvious relevance. The following are what might be considered the standard features:

1. At least three appearances of a distinctive thematic section.

2. Each appearance starts and remains in the same key.

3. The appearances of the main theme were normally closed structures ending in a cadence in the tonic key.

4. Returning sections are identical or nearly so.

5. Intervening episodes have contrasting key and thematic material.

6. The proportions of theme and episode are generally comparable, although it was quite common for some episodes to be longer.

3 Some idea of the range of conflicts appears in my paper. 'The Schizophrenia of Mahler's Middle-Period Symphonies', given in Utrecht in August 1996 as part of the Fifth Conference of the International Society for the Study of European Ideas (CD-ROM: Utrecht, University of Humanist Studies, 1998). Printed publication by MIT Press, Boston is forthcoming. 
7. Episodes normally lead without a break into the return of the main theme, often with a clearly defined preparatory section in the dominant key.

Cedric Thorpe Davie rightly includes this in his treatment of what he calls "Expansion of the 'closed' principle ${ }^{4}{ }^{4}$ Heinrich Schenker also dealt with the Classical formulation in his approach to the rondo in Der freie Satz.

Before looking at the movements in detail it will be useful to give some indication of how Mahler used the rondo principle. The classical plan given by Davie and Schenker is modified in a number of ways. The first and most obvious is that there are very few instances in which a theme returns without some fundamental modification, for example, melodic variation, harmonisation scoring, or even tonality. The treatment of the episodes is also very variable: in some cases they follow the Classical idea fairly strictly, but more often the proportions are varied, from one episode to the next, whether they are thematically similar or not. The thematic material of both rondo themes and episodes can consist of a number of constituent sections, with interleaving and reordering between different episodes. One feature that is very common in these symphonies is the progressive contraction of musical material at each rondo reappearance. Another feature which is of cardinal importance to the living form as we hear it and not to the classical stereotype is the climax reached in many movements which leads in some cases to a breakthrough or equally often a collapse of the melodic and harmonic material. This should lead us to explore the idea that Mahler was best able to show us his narrative or the 'progress' of his musical materials by presenting the familiar (the rondo 'theme') in different forms and in different contexts. This idea of varied reprise which is of course normal in Mahler's music takes on a basic structural purpose, as a pointer to some form of resolution, in some cases the disintegration of the music. The biggest problem in this discussion is the ability to make a distinction between the development of any given material and a reprise. To what extent is any thematic material similar and to what extent is it different? It is possible that as a result of this investigation we can find a narrative interpretation of the music, but obviously we must take the warnings of Jean-Jacques Nattiez and Michel Imberty seriously. ${ }^{6}$

The present paper aims to determine to what extent Mahler's apparent use of the rondo is a reality or an illusion; whether the reality fits the model or whether the model is totally irrelevant to the reality. Numerous movements in these symphonies can be interpreted as rondos. Of all the fourteen movements of the Fifth, Sixth and Seventh Symphonies, we can exclude, at least for the moment, the first movement of the Sixth with its masterly but relatively straightforward sonata structure and the Adagietto of the Fifth with its ternary plan. The remaining twelve movements fall into different categories that all have a bearing on the rondo issue. For the present study the following terms are adopted:

4 Cedric Thorpe Davie, Musical Structure and Design (London: Dennis Dobson, 1953), $39-52$.

5 Heinrich Schenker, Free Composition (New York: Longman, 1979), 141-43.

6 Jean-Jacques Nattiez: 'Can one speak of narrativity in music?', Journal of the Royal Musical Association 115 (1990) 2, 240-57; Michel Imberty, 'Can One Seriously Speak of Narrativity in Music?', Proceedings of the Third Triennial ESCOM Conference Uppsala Sweden 7-12 June 1997(Uppsala: Uppsala University, 1997), 13-22. 


\section{MUZIKOLOŠKI ZBORNIK • MUSICOLOGICAL ANNUAL XXXV}

1. implicit rondo for those movements with recurring thematic material but which are not specifically called rondos (5/i, 5/ii, 5/iii, 6/ii (Andante), 6/iii (Scherzo), 7/ii, 7/iii, 7/iv)

2. explicit rondos for those movements that are actually called 'rondo' (5/v, $7 / \mathrm{v})$

3. related movements for those movements which while not fitting the rondo idea have some features which are relevant to the ideas put forward here $(6 / \mathrm{iv}, 7 / \mathrm{i})$

\section{Implicit Rondos}

Let us examine the movements in the first category, the implicit rondos. The first, second and third movements of the Fifth have rondo-like features, even if other models can be plausible. Floros, Cooke and Kennedy ${ }^{7}$ describe the Fifth's first movement as a march with two trios. Murphy, ${ }^{8}$ however, insists that the two contrasting sections are too heavy to carry the title 'trio'. This apparently trivial disagreement immediately raises another issue: do we consider the scherzo and two trio form as a rondo or not? They all agree on the ABABA plan, but does this represent Mahler's actual music? The most obvious feature is the trumpet fanfare, derived from a passage in the first movement of the Fourth Symphony. It appears first unaccompanied, and after the contrasting march, fully harmonised. After an extended version of the march, the fanfare briefly introduces the extended Leidenschaftlich central section in B flat minor. The return of the full fanfare is differently scored, followed by the march. A timpani version of the fanfare figures leads to a reworked version of the $\mathrm{B}$ flat minor music. The interesting point is the climax of the music at fig 18 and its collapse into the dismembered fragments of the fanfare that conclude the movement. A revised scheme could be given as the following: $\mathrm{ABA}_{1} \mathrm{BaCA}_{2} \mathrm{~B}_{1} \mathrm{a}$ $\mathrm{C}_{1} \mathrm{~A}_{3}$. If one simplifies the plan we get $\mathrm{ABABCABCA}$. The rondo character of the plan is then clear, but Mahler's distinctive contraction of the main theme at each successive appearance is not. Its developing character until the final collapse is typical of the composer.

Table 1 Symphony No. 5 (First movement: Trauermarsch)

\begin{tabular}{|l|}
\hline $\begin{array}{l}\text { simple version } \\
\mathrm{A} B\end{array} \quad \mathrm{~A} \mathrm{~B} \quad \mathrm{~A}$ \\
\hline more elaborate version \\
$\mathrm{A} \mathrm{B}$ A B C A B C A \\
\hline complete version with links \\
$\mathrm{A} B \mathrm{~A}_{1} \mathrm{~B}$ a C $\mathrm{A}_{2} \mathrm{~B}_{1}$ a $\mathrm{C}_{1} \mathrm{~A}_{3}$ \\
\hline
\end{tabular}

The second movement provides no more comfort for those trying to understand the work using traditional criteria. Floros with some justification presents the simple

7 Constantin Floros: Gustav Mahler: the symphonies (Aldershot: Scolar, 1994); Deryck Cooke, Gustav Mahler: an Introduction to his Music (London: Faber, 1980); Michael Kennedy: Mahler (London: Dent, 1974).

8 Edward Murphy, 'Unusual Forms in Mahler's fifth Symphony', The Music Review 47 (1986-87), 101. 
plan of exposition-development-recapitulation-coda, while Murphy 9 surprisingly settles for the simple rondo plan: ABABA. In actual practice we have something far more interesting. Cooke put his finger on the problem: 'each appearance occurs three times, ever more varied in treatment and shorter in span' ${ }^{10}$ The climax is reached with a brass chorale. Cooke continues with his description: 'Then it the brass chorale fades with the swiftness of a dream; the main material returns for the last time to end the movement in a deathly whisper.' The deliberately chaotic return of the opening two sections after the fading of the D major chorale at the climax is brilliantly handled with a collapse into thematic fragments and reverting from $\mathrm{D}$ major back to A minor. Mahler has varied the process of the first movement. One feature of these two movements deserves further comment: the use of some common thematic material. If one traces the progress of the horn theme first heard in the $\mathrm{Bb}$ minor section of the first movement and disregards the tonalities, one can hear another kind of rondo functioning, alongside the plans already in place within each movement, that runs across the two movements. It is a feature that appears later in this symphony, as well as in the Sixth.

Table 2 Symphony No. 5 (Second movement: Stürmisch bewegt)

simple version (Murphy)
A B A B A
more complex interpretation
A B A $A_{1} B_{1} C A_{2} B_{2} C_{1}$ (Chorale) $A_{3}$ Coda

The scherzo which follows is a particularly good example of the way that ambiguity of form can be exploited. Cooke wrote: 'the excited Ländler music...returns all the time, in rondo fashion', ${ }^{11}$ while the perceptive but non-academic Neville Cardus ${ }^{12}$ expressed himself in more flowery language: 'The student will enjoy himself seeking to point exactly where one trio of the movement ends and the other begins, so cunningly integrated is each part of the whole, a synthesis of Ländler, Waltz and rondo elements.' Adorno ${ }^{13}$ noted that Mahler integrated all the elements and referred to the development-scherzo, a point also taken up by Robert Samuels.$^{14}$ In line with this and in his usual way, Floros looks to the sonata model as $\mathrm{ABA}_{1} \mathrm{CDA}_{2} \mathrm{Coda}$. Murphy sticks to the rondo idea in the more complicated scheme of ABACDADCA. ${ }^{15}$ What then is the reality? It is a combination of both of these with the traditional scherzo and with two trios. To try to label it as any one of these is futile, as Mahler drew on all three for his scheme.

9 Ibid., 104.

10 Cooke, op. cit., 82.

11 Ibid., 83.

12 Neville Cardus, Gustav Mahler: his mind and his music (London: Gollancz, 1965), 180.

13 Adorno, op. cit., 102.

14 Robert Samuels: Mahler's Sixth Symphony: A Study in Musical Semiotics (Cambridge, Cambridge UP, 1995), 110-15.

15 Murphy, op. cit., 105. 
MUZIKOLOŠKI ZBORNIK • MUSICOLOGICAL ANNUAL XXXV

Table 3 Symphony No.5 (Third movement: Scherzo)

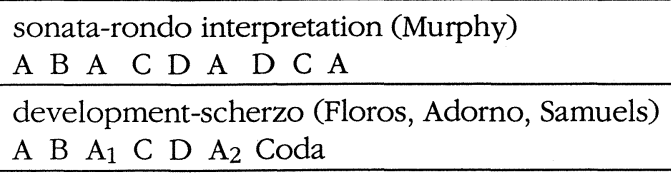

The two middle movements of the Sixth have rondo features, exhibiting the usual forms of reprise with variation that were found in the Fifth Symphony. This study will address the Andante moderato first. There is general agreement that this movement is a rondo. Floros, Del Mar, Samuels, Kennedy, and Jülg ${ }^{16}$ all agree on this point. The basic form that it takes is ABABA and coda. The lengths of each of the sections vary considerably. This is no surprise in Mahler, but here there is a good reason. The first 55 bars includes two statements of the theme in the tonic key, separated by a short passage of contrasting thematic material. As the music of this apparent linking passage is taken up again in the extended episode at bar 56 and again after a further return of the theme at bar 139, there is good reason, despite its brevity, to consider it a contrasting episode. It is interesting that Jülg in his chart makes this very point by referring to the Hauptthema in this passage. ${ }^{17}$ This then makes a larger type of rondo: ABABABA. Typically the theme itself is subjected to considerable changes at each appearance, with the last version starting surprisingly in $\mathrm{B}$ major before moving to the conclusion in $\mathrm{E}$ flat major. The progress of the theme is different from that of those of the opening movements of the Fifth, as there is no appreciable contraction of the length of the theme and there is no dramatic collapse of the music after the climax. After the climax, the music gradually and naturally thins out to the final bars.

Table 4 Symphony No. 6 in A minor (Andante moderato)

\begin{tabular}{|llllllll|}
\hline simple version & A & & & B & A & B & A \\
\hline full version & & & & & & & \\
Sections: & A & B & A & B & A & B & A \\
Number of bars: & 20 & 7.5 & 26 & 46 & 15 & 45 & 42 \\
Key centres: & Eb & Gm & Eb & Em/E & Eb C/A/E & B-Eb \\
\hline
\end{tabular}

The Scherzo's form is unambiguously one of Mahler's rondo extensions of the scherzo with repeated trio $\left(\mathrm{ABA}_{1} \mathrm{~B}_{2} \mathrm{~A}_{2}\right.$ coda). The contractions of the lengths of each of the scherzo sections (all in A minor) are dramatic ( 97 bars, 74 bars, 37 bars), leading to the final collapse. The two trios, however, maintaining a similar length and using a parody style, are in $\mathrm{F}$ and $\mathrm{D}$ major respectively, mirroring the principal key

16 Floros, op. cit., 178; Norman Del Mar, Mahler's Sixth Symphony: A Study (London: Eulenburg, 1980), 41; Samuels, op. cit., 55-56; Kennedy, op. cit., 121: Hans-Peter Jülg: Gustav Mahlers Sechste Symphonie (Munich: Katzbichler, 1986), 99.

17 Jülg, op. cit., 99. 
areas of the first movement's subsidiary material. The coda breaks down the basic A minor tonality to an alternation between the notes $\mathrm{C}$ and $\mathrm{A}$, with the accents just as often placed on the Cs as on the As. The significance of this will now become clear.

Table 5 Symphony No. 6 in A minor (Scherzo)

\begin{tabular}{|lllllll|}
\hline simple version & A & B & A & B & A & Coda \\
\hline detailed version & & & & & & \\
Sections: & A & B & $\mathrm{A}_{1}$ & $\mathrm{~B}_{2}$ & $\mathrm{~A}_{2}$ & Coda \\
Number of bars: & 97 & 102 & 74 & 100 & 37 & 38 \\
Key centres: & Am & F & Am & D & Am & Am \\
\hline
\end{tabular}

The 'progress' of Mahler's music here allows us to draw some conclusions and cast light on the vexed question of the order of these two movements. The melodic and emotional character of the Andante moderato has more in common with the second subject of the first movement than anything in the scherzo or finale, making its position before the scherzo plausible. The reappearance of the chorale from the first movement in the Andante moderato (immer mit bewegter Empfindung)(b.165) further binds the movements together. It could almost be taken as another (rondo) appearance of the first movement's chorale. Neither movement has anything like the collapse of the scherzo or finale of this symphony or that encountered in the first two movements of the Fifth. In emotional terms the Sixth's scherzo is more in character with the finale with its huge and overpowering final collapse. The actual linking of the scherzo with the finale can be seen in the insistence of the scherzo's coda on the notes $\mathrm{C}$ and $\mathrm{A}$, in line with the conflicting tonalities ( $\mathrm{C}$ minor and $\mathrm{A}$ minor) found at the beginning of the finale. Adorno's linking of $\mathrm{E}$ flat major directly with $\mathrm{C}$ minor is not part of Mahler's normal practice which usually involved making sudden shifts from major to minor or vice versa, and exploring mediant relationships. While Mahler did have some indecision about the better order of these two movements, this does put considerable doubt on the rather glibly accepted orthodoxy of Erwin Ratz and Adorno that the Scherzo should precede the Andante moderato. ${ }^{18}$

To turn to the three central movements of the Seventh is in some ways simpler and in others more difficult. Mahler's form has now become even more flexible and less easy to map on to the classical model, but it is clear what he was doing. One feature which adds an additional dimension to his structure is the introductory material. This already formed part of the technique of the finale of the Sixth Symphony and the first movement of the Seventh, and is now used in both the second and third movements. Floros ${ }^{19}$ identified the two thematically related parts of the opening of the second movement as 'introduction' and 'main section'. The first time they return they are separated and finally reversed at the ending prompting the plausible reference to 'arch form'. ${ }^{20}$ The way that this appears can be simplified as follows:

18 Erwin Ratz in the introduction to the Internationalen Gustav-Mahler Gesellschaft score (Lindau-Bodensee: Kahnt, 1963); Adorno, op. cit., 85.

19 Floros, op. cit., 198. 


\section{MUZIKOLOŠKI ZBORNIK • MUSICOLOGICAL ANNUAL XXXV}

IM...I.M.MI. ${ }^{21}$ Floros confused matters by calling some appearances of the theme 'intermezzo'. The implication is that there is some clear-cut distinction between the two, but there is a problem in that they are thematically closely related. The passage at bars 122-140 with the cowbells is a suspension of time, but is it thereby distinguished from the other appearances of the 'main section'? Davison refers to an otherwise clearly defined formal pattern (ABACAB) disrupted by 'the presence of cowbells, echoing horns, march music and exotic dance rhythms'. ${ }^{22}$ We can note that the variants of the main section are not as drastic as is often the case in Mahler's music. There is contraction in the repeated appearances $(53,38$ and 24 bars respectively), but there is no collapse.

Table 6 Symphony No.7 (Second movement: Nachtmusik: Allegro moderato)

$$
\begin{aligned}
& \text { Simple version (sonata model) } \\
& \text { A B C A B C Development A B C.Coda }
\end{aligned}
$$

Floros

$\mathrm{I}-\mathrm{M}-\mathrm{T} 1-$ Intermezzo - T2 - I - T2 - M - T1 - M - I

Note: $\mathrm{I}=$ Introduction, $\mathrm{M}=$ Main section, $\mathrm{T} 1=$ Trio $1, \mathrm{~T} 2=\mathrm{Trio} 2$

The scherzo seems at first to be a straightforward scherzo and trio, but the use of introductory material, the incorporation of a waltz into the structure, a false reprise not in the tonic key, and considerable variants on the reprises make this movement more complicated than it originally seemed. As in the previous movement there is some doubt in the listener's mind as to whether A or B is repeating or rondo material, or whether in fact we have a rondo at all. It is at this stage that we must ask ourselves whether the proliferation and combination of motifs in this movement make the idea of any kind of simplistic formal analysis increasingly irrelevant. ${ }^{23}$

Table 7 Symphony No. 7 (Third movement: Scherzo: Schattenhaft)

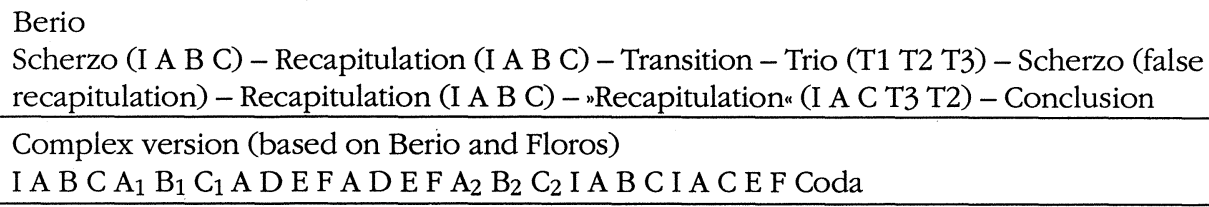

Note: $\mathrm{I}=$ Introductory material

20 Ibid, 198

21 I=Introduction, M=Main section. The dots represent contrasting sections which Floros calls Trio I and Trio II(separated by the return of the Introduction into two parts). See Table 6 for full version.

22 Peter Davison, 'Nachtmusik I: Sound and Symbol', in James L. Zychowicz, The Seventh Symphony of Gustav Mahler. A Symposium (Cincinnati: University of Cincinnati College-Conservatory of Music, 1990), 68.

23 Talia Pecker Berio, 'Perspectives of a Scherzo' in Zychowicz, op.cit., 74-88. 
When we turn to the fourth movement, Andante amoroso, the standard rondo plan looks increasingly inapplicable. Davison attempts to strike a balance between sonata and ternary forms. ${ }^{24}$ Floros ${ }^{25}$ rightly points to the recurring theme within the larger structures $\left(\mathrm{ABA}_{1} \mathrm{CA}_{2}\right.$ in the opening section) The development section then shows a similar repetition, while the 'trio' (Floros) is in reality a ternary interlude.

Table 8 Symphony No.7 (Fourth movement: Nachtmusik: Andante amoroso)

\begin{tabular}{|llll|}
\hline $\begin{array}{l}\text { Simple scheme } \\
\text { Intro - Main section - Trio I - Intermezzo - Trio II - Intro - }\end{array}$ & Trio II & \\
\hline Davison A B A & C & A B & \\
\hline $\begin{array}{l}\text { Floros } \\
\text { Main section } \\
\text { Refrain - A - B - } \mathrm{A}_{1}-\mathrm{C}-\mathrm{A}\end{array}$ & Development Trio & $\begin{array}{l}\text { Recapitulation } \\
\text { Refrain }-\mathrm{A}-\mathrm{B}-\mathrm{A}_{1}-\mathrm{C}-\mathrm{A}\end{array}$ & Coda \\
\hline
\end{tabular}

The progressive narrative character of the middle movements of the Sixth Symphony is replaced in the three central movements of the Seventh by a more static and descriptive character. Davison points very precisely to this in hermeneutic terms. ${ }^{26}$ There is no sense of breakthrough or collapse that we find in the outer movements. What may be happening is the suspension in these movements of the kind of progression that we might have been led to expect from the first movement.

\section{Explicit Rondos}

The finales of the Fifth and Seventh Symphonies are called 'Rondo' by Mahler. While this would appear to put the matter beyond any doubt, it does in fact produce even more of Mahler's legendary ambiguity. These two movements diverge as far from classical rondo form as they do from each other.

By the broadest definition, there are three types of rondo operating in the final of the Fifth Symphony. The first and most obvious is found in the appearances of the D major 'Rondo' theme, based loosely on the Classical model. This can be heard twice, at bars 24 and 136, and in the varied version at bar 497 which fulfils rondo expectations because of the long dominant pedal preparation. The final version of this theme can then be seen as the chorale at bar 711, in augmented form, except that it derives more from one of the other motifs. ${ }^{27}$ The second rondo process of the movement is found in the five fugal episodes that use motifs from the movement's introduction, what might be called a rondo by texture. Admittedly the tonalities chosen

24 Peter Davison, 'Nachtmusik II: "Nothing but Love, Love, Love"?' in Zychowicz, op. cit., 93.

25 Floros, op. cit., 204.

26 Davison, op. cit., 69-73, 89-97. The mention of Eichendorff is particularly relevant to the second movement, but in fact the shadow that hangs over the whole symphony is spelled out by Mahler himself as reported by Davison on p.90.

27 Henry-Louis de La Grange, Gustav Mahler vol.2 (Oxford: Oxford UP, 1995), 819-25; Carolyn Baxendale, 'The Finale of Mahler's Fifth Symphony: Long range musical thought', Journal of the Royal Musical Association 112 (1987) 2 , 257-89. 
and the actual motifs used show considerable variety. The third rondo process can be seen as more speculative and controversial. This involves the theme of the central section of the preceding ternary Adagietto, which then appears in three places in the finale (b.191 B major, b.373 D major, b.623 G major), making a total of four appearances. It mirrors the same type of process that can be traced in the first two movements.

Table 9 Symphony No.5 (Rondo-Finale: Allegro-Allegro giocoso)

\begin{tabular}{|l|}
\hline simple interpretation \\
Intro A B A B A B Chorale Coda \\
\hline more complex including grazioso sections (based on Floros) \\
Intro A B A B X B X B A B A A Chorale Coda \\
\hline
\end{tabular}

Note: $\mathrm{X}=$ derivative of Adagietto central section

Mahler also entitled the fifth movement of the Seventh Symphony Rondo-Finale. It has been the subject of a great deal of criticism from various quarters. The apparent overuse of the key of $\mathrm{C}$ major and the lack of thematic development are the most important of these. The organisation of the music underlies some of these criticisms. As in the Fifth Symphony, Mahler presented a number of different materials, but unlike in the Fifth, these actually constituted the rondo materials. For each appearance of the 'rondo' Mahler used only some of these materials. The movement operates more like a Baroque ritornello (both Floros and Scherzinger ${ }^{28}$ use this term), with the complete version (all six parts) only at the beginning and the end. In the intervening six versions Mahler presented the music less than complete. Apart from the first three appearances and the last, he avoided $\mathrm{C}$ major.

Table 10 Symphony No.7 (Rondo-Finale: Allegro ordinario)

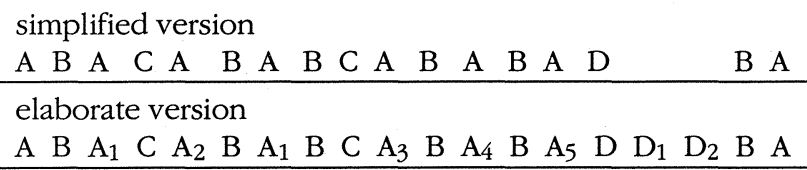

\section{Related movements}

Two other related movements can also be considered in this generic context: the finale of the Sixth Symphony and the first movement of the Seventh. Neither is described by the composer as a rondo. They can, however, offer some insight into Mahler's use of the rondo in other movements.

The finale of the Sixth is an amazing conglomerate that has been variously interpreted by different commentators. The basic sonata structure of the movement is

28 Floros, op. cit., 206-11; Martin Scherzinger, 'The Finale of Mahler's Seventh Symphony: A Deconstructive Reading', Music Analysis 14 (1995)1, 69-88. 
concealed by a number of features: the half-hour length, the use of a slow introductory section that returns three times, the reversal of the positions of the first and second subjects in the recapitulation and the contrast of slow and fast passages. ${ }^{29}$ The rondo idea of the movement is found in the appearance of the long soaring melody which appears at various important structural points: the opening, the beginning of the development, the beginning of the recapitulation, and the beginning of the coda. It functions in something like the main theme of the finale of Mozart's Symphony No. 35 in D K385 (Haffner), although there are numerous fundamental differences.

Table 11 Symphony No.6 (Finale)

\begin{tabular}{|lllll|}
\hline Sections: & Intro A B & Intro Development & Intro B A & Intro Coda \\
No. of bars: & 15 & 7 & 17 & 17 \\
Key centres: & $\mathrm{Cm}$ & $\mathrm{Dm}$ & $\mathrm{Cm}$ & $\mathrm{Am}$ \\
\hline
\end{tabular}

The first movement of the Seventh Symphony has been looked upon as a type of episodic model, not without its connections to the rondo ideal. The use of a slow introduction that is integrated into the structure of the movement makes for a certain complexity. Floros sees this as a sonata-type movement, ${ }^{30}$ while Murphy tries to use his universal sonata-rondo to make sense of it. ${ }^{31}$ The latter's presentation of this model fails to convince for a number of reasons. The development (Murphy's C section) is out of all proportion to the so-called rondo theme and the integration of the introduction (Arioso) into the main movement causes structural difficulties that Murphy's table ${ }^{32}$ studiously avoids. Williamson also quite rightly views the nature of the theme as not exhibiting rondo characteristics. ${ }^{33} \mathrm{He}$ treads much more carefully, presenting a type of episodic model that sits somewhere between the two.

Table 12 Symphony No. 7 (First movement)

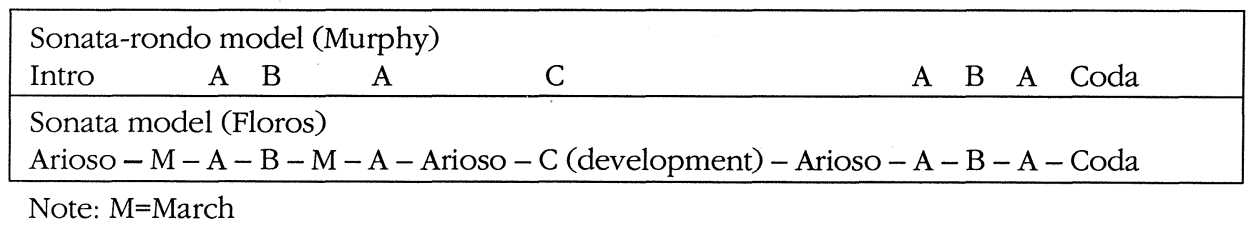

While some of these interpretations can stretch our credibility, especially if they are taken literally, there is some truth in most of them. Moreover, the many contra-

29 See the excellent tables in Samuels, op. cit., 72-75 for a comparison of the detailed analyses.

30 Floros, op. cit., 192-93.

31 Murphy, 'Sonata-Rondo Form in the Symphonies of Gustav Mahler', The Music Review 36 (1975) 1, 60-61.

32 Ibid, 60.

33 John Williamson, 'Mahler and Episodic Structure: The First Movement of the Seventh Symphony' in Zychowicz op. cit., 31 . 
dictions thus revealed can give us an insight into Mahler's methods of working. It is not difficult to recognise the inconsistencies where they exist. By analysing aspects of the composer's style, for example, tonality and the use of motives, it is possible to give some idea of what Mahler's compositional philosophy was and how his working methods relate to it.

\section{Problems}

A number of problems remain. They concern two features in particular: similarity and context. The most obvious is that Mahler's use of recurring thematic materials can hardly ever, if at all, be taken literally to represent the strict Classical rondo. Mahler's themes are duplicated exactly only in literally repeated sections, for example the repeated exposition of the first movement of the Sixth Symphony. Changes of melodic shapes, rhythmic patterns, harmonisation and tonality, and instrumentation are the most obvious aspects. The big problem with this music is how much change can we accept while still recognising some valid form of similarity.

The second criterion is that of context. Must rondo themes operate within closed structures in a single tonality or can we accept any tendencies to move towards the dominant? Clearly this dichotomy led Edward Murphy to propose the sonata-rondo model for a number of Mahler's movements. Generally it has a certain plausibility, but like most monolithic theories of interpretation and analysis of Mahler's music, it has a number of limitations and inconsistencies. The other contextual feature that we must consider is that of preparation for the rondo return. In Classical practice this normally involved some form of dominant preparation, typically a dominant pedal. Mahler tends not to use this technique, usually approaching by some form of oblique key switch. Even so there are two striking examples in the finale of the Fifth Symphony, before the third appearance of the rondo theme and before the reappearance of the chorale near the end of the movement.

The final issue that must be considered is to what extent did Mahler want his audience to think about and keep a mental record of different cycles of recurring thematic materials operating simultaneously. This has profound implications for our understanding of the overall structural sense of the Fifth and Sixth Symphonies.

\section{Deductions and conclusions}

Three clear choices seem to present themselves at this stage:

1. are we looking at the dying spasms of an outdated form?

2. is it simply the inconsistency of transition?

3. are we encountering an intuitive narrative overlay on a traditional model?

Let us look at these in turn.

Was the rondo 'outdated' in Mahler's time? Mahler almost always in his symphonies planned his movements according to some derivative of a classical model: ternary, rondo, scherzo and trio, sonata form. (His use of formal variation technique is extremely rare, for example, in the slow movement of the Fourth Symphony.) How- 
ever, he never adhered fully to the conventions of these models, almost always choosing some form of flexibility and sometimes blurring the distinctions between the different forms. Many of his contemporaries did very much the same, so in this sense, his methods were not that exceptional. On the other hand when we look at composers who followed Mahler, very few, apart from those employing pastiche techniques, actually used rondo form. In an obvious sense then, its days were certainly numbered.

The second point can be treated simply. Mahler had a foot in both camps. His music almost always has a firm foundation in traditional means and techniques, but he almost always had a new way of using them. To say that this is the inconsistency of transition is misleading. It suggests that Mahler had an uncertain aim. To be sure Mahler often had doubts about some of the details of his works, notably in their scoring, but his overall aim was as secure as that of any composer who was breaking as much ground as he was.

The third possibility, the idea of a narrative overlay on a traditional model is an appealing option and one that has attracted much attention. The return and transformation of the rondo themes and their contrast with the intervening episodes forms the progress of the narrative. The idea of the rondo themes representing the characters (Adorno) is certainly plausible so long as one does not take the term too literally. This does have some implications for the interpretation and understanding of these three symphonies.

In the Fifth Symphony we can take part one (movements 1 and 2) as an interconnected series of recurring minor-key sections, much of march-like character, which reach their climax at the D major chorale near the end of the second movement. It is the rondo-like elements that build up the tension and expectation. The music collapses into A minor in some kind of 'failure'. Part two (the scherzo) reintroduces D major now in an exuberant dance-related context. Part three (Adagietto and RondoFinale), almost exclusively in major keys, presents another interlinked series of three 'rondo' materials: the middle section of the Adagietto and its related grazioso of the finale; the finale's main rondo theme itself; and the five fugal episodes. As in part one the music reaches a climax in the appearance of the same D major brass chorale. In contrast to the collapse in part one, the music remains firmly anchored in $\mathrm{D}$ major right up to its triumphant conclusion. The narrative relates to the significance of major and minor keys, and the opposition of the march to the dance. 
Table 13 Symphony No. 5

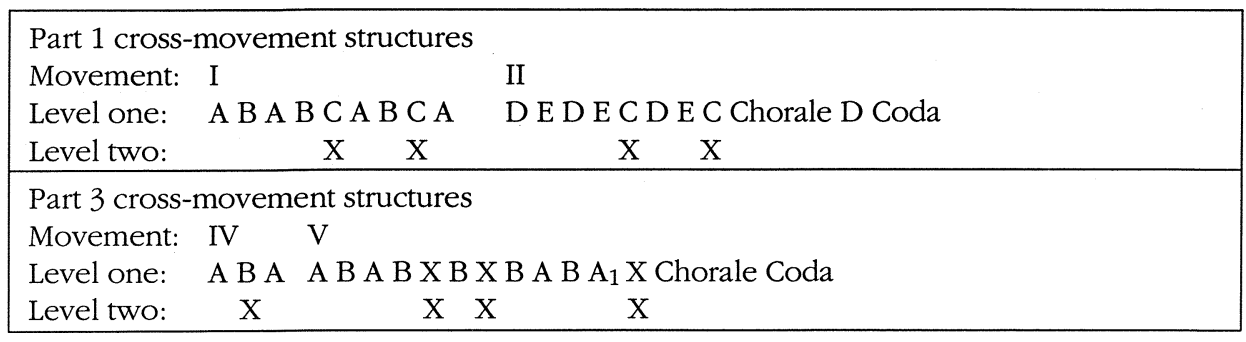

Note: In part 2, $\mathrm{X}=$ Adagietto theme from central section.

In the Sixth Symphony the process is reversed but in order to see the full significance of this, however, one must use the original order of the middle movements to which Mahler returned at the first performance and for the revised publication. In this format the first two movements contain the triumphant climaxes, the third and fourth movements the collapses. The conflict between the A minor march material of the first movement (perhaps the 'Gustav' music) and the 'Alma' theme results in a triumph for the latter. The three appearances of the chorale in the first movement separated the two predominant themes, The return of the chorale at the climax of the almost totally major music of the Andante has some hidden significance: it is perhaps stretching credibility to say that it is a fourth appearance of a 'rondo' theme, but it certainly connects the first movement with the Andante moderato. It momentarily distorts the tonality of the final return of the Andante moderato's rondo theme.

Table 14 Symphony No. 6

\begin{tabular}{llll}
\hline cross-movement structures & & \\
Movement: & I (Allegro energico) & II (Andante moderato) \\
Level one: & A B A B Dev A B A B & A B A B A \\
Level two & X A X & X & X
\end{tabular}

Note: $\mathrm{X}=$ Chorale

The scherzo and finale now turn the triumphs on their head. The scherzo parodies the first movement, tonally, rhythmically and thematically. Its three-in-a-bar music sardonically mocks the march material, while the keys of the two trio sections ( $\mathrm{F}$ and $\mathrm{D}$ major) mirror in parodistic fashion the predominant keys of the positive 'Alma' music. The main scherzo section is progressively contracted at each appearance with a devastating collapse at the third time. As noted above the collapse ends by emphasising the two notes $\mathrm{A}$ and $\mathrm{C}$, significantly the key-notes of the two minorkey tonalities that dominate the early part of the finale which results in the biggest collapse in all of Mahler's music. In a word the rondo idea provides the key to the understanding of the work.

The narrative interpretation of the Seventh Symphony takes us into the realms of speculation. The rondo idea is not so strong in this work, except in the finale, but it 
gives us a clue as to Mahler's aims. Taking a cue from Davison ${ }^{34}$ it seems that the symphony can be interpreted in a number of ways: it could be thought of as the composer's 'Romantic' symphony; it is not difficult to see it as a symphony of love, but perhaps best of all it can be viewed as Mahler's first Faust symphony, on the Lisztian model (the Eighth is the second). The first movement presents Faust and Gretchen, the second Faust, the third Mephistopheles, the fourth Gretchen, and the finale the triumph of love. The first movement contrasts two thematic groups not dissimilar to the equivalent sections of the Sixth Symphony but the progress is much more discursive. The fact that they are subjected to a number of different adventures is made clear by Williamson. ${ }^{35}$ The appearance of the sinister scherzo with its constant returns - could there be some significance in the 'false' recapitulation? - separating the two Nachtmusik movements has obvious Mephistophelean overtones. Perhaps Mahler had to express the triumph of love over the devil in the finale in such an emphatic, repetitive and bombastic fashion in order to purge the horrendous experience of the devastation of the Sixth Symphony.

This brings us full circle to the question implied in my title. Is Mahler's use of the rondo in his middle period symphonies a valid model or a useful abstraction? Clearly Mahler did not use the Classical form literally, but rather in flexible and daring way. 'Valid model' is hardly an accurate description of this state of affairs. Many writers both implicitly and explicitly go so far as to deny that Mahler was concerned with the rondo idea at all. Perhaps we should follow them and refer to Mahler's apparent use of the rondo and go one stage further, drop the term 'rondo' completely and refer in a more accurate but prosaic fashion to his use of 'recurrent loosely related musical materials'. Whatever term one uses, and I prefer 'useful abstraction', this technique provides one and only one useful key to understanding the strategic aims of these endlessly fascinating musical documents.

\section{Rondo $v$ Mahlerjevih simfonijah iz srednjega obdobja: utemeljen model ali uporabna abstrakcija}

\section{Povzetek}

Mahlerjeva Peta, Šesta in Sedma simfonija so polne različnih glasbenih protislovij. Stojijo na razvodju $v$ skladateljevem razvoju: občasno opozarjajo na slog Wunderhorn, čeprav $z$ novimi tehnikami ter neobičajnimi zvočnimi barvami, sorodnimi z zvoki, ki so jih navdihovale uglasbitve Rückertovih pesmi. Čeprav je Mahler te elemente mojstrsko povezal, ostaja omenjena dvojnost še vedno pomembna poteza njegovih del. Zlasti je pomembna skladateljeva raba oblike $v$ teh delih. Na nek način je tradicionalna, kar je seveda del njene privlačnosti, na drugi strani pa je prilagodliviva, moderna in povsem izvirna. Značilna poteza Mahlerjeve uporabe forme je način, na kakršen se vedno znova vrača $k$ osnovnemu tematskemu gradivu. V preprostem ali poenostavljenem smislu gre za rondo. Vpričujočem prispevku želi avtor dognati, ali je Mahlerjeva očitna raba rondoja resničnost ali le slepilo. 
Številni stavki teh simfonij so navidez rondojski. Finale Pete in Sedme simfonije sta označena kot rondoja, čeprav obstaja znatno nesoglasje glede podrobnosti. Prvi, drugi in tretji stavek Pete ima rondojske poteze, čeprav so možni tudi drugi modeli, medtem ko lahko podobno označimo tudi oba srednja stavka Šeste. Tudi za tri srednje stavke Sedme lahko prav tako rečemo, da vsebujejo rondojske poteze. Pa tudi oba preostala stavka lahko obravnavamo $v$ istem splošnem kontekstu. Prvi stavek Sedme je napisan epizodno, znova ne brez povezav $z$ rondojskim idealom. Finale Šeste je presenetljiv konglomerat, ki so ga razlagalci različno tolmačili. Podrobna obravnava določenih aspektov tega stavka odkriva določene rondojske poteze.

Medtem ko je lahko verodostojnost nekaterih od teh interpretacij vprašljiva, še posebno če jih razumemo preveč strogo, vendar $v$ določeni meri veljajo. Razen tega lahko mnogo nasprotij, ki smo jih tako odkrili, razkrije Mahlerjev način dela. S pomočjo analize aspektov skladateljevega sloga, npr. tonalnosti in uporabe motivov, je možno ponuditi nekaj hipotez o tem, kakšna je bila Mahlerjeva kompozicijska filozofija in kako so z njo povezane njegove delovne metode. Imamo tri možne jasne izbire: ali gledamo smrtni krč zastarele forme, ali se soočamo $z$ intuitivno narativno prevleko na tradicionalnem modelu ali pa gre preprosto za protislovje prehodnega obdobja. 